\title{
CONDITIONS OF RURAL DEVELOPMENT IN THE WARMIA AND MAZURY VOIVODESHIP (POLAND) IN THE OPINION OF LOCAL AUTHORITIES
}

\author{
Iwona Pomianek, $\mathrm{PhD}^{1}$ \\ Faculty of Economic Sciences, Warsaw University of Life Sciences - SGGW
}

\begin{abstract}
The aim of the paper was to identify positive as well as negative local development factors in the opinion of the authorities (mayors) of rural and semi-urban (urban-rural) municipalities in the Warmia and Mazury Voivodeship, Poland. The research was based on a survey within local authorities of the Warmia and Mazury region and was carried out in 2017. The results show that the local authorities have been aware of numerous opportunities and barriers of local economic development. Sometimes, if there is one barrier, it causes the formation of new ones, for example the shortage of own financial resources or municipal debt make it impossible to finance investments from the local budget or to apply for EU funds, which require co-financing from the beneficiary's own resources. Most of mayors make efforts to mitigate exogenous conditions by local activeness, such as co-operation with neighbouring or foreign municipalities or offering preferential tax rates to investors. Municipal authorities perceive the opportunity in applying for EU funds for projects aimed at improving the quality of life of local communities, including the development of technical and social infrastructure.
\end{abstract}

Keywords: rural areas, local development, development factors

JEL codes: O11, O18, R51, R56

\section{INTRODUCTION}

In the experience of Poland and other countries, it is observed that local authorities can play a very important role in promoting economic development (Kotala and Basaj, 2004; Wiatrak, 2006). However, there is one condition: the management methods used by local authorities should change to more modern ones and local governments must adapt techniques and methods of strategic management used by private companies, including strategic management. Responsibility for local (municipal) development and the standard of living of inhabitants in the conditions of a market economy imposes entirely new tasks on local authorities (Kłodziński, 1996; Zalewski, 2006; Wiatrak, 2011). Municipal authorities, for example, can become a factor accelerating development of small enterprises in their area, but through a precipitate attitude to enterprises, local governments can also constitute a strong barrier to their formation and development (Kłodziński and Rosner, 1995). Moreover, the amount of funds allocated by the municipality to investment is an essential issue in shaping local development (Klank,

\footnotetext{
${ }^{1}$ Corresponding author: Nowoursynowska 166,02-787 Warsaw, Poland, iwona_pomianek@sggw.pl
} 
2005). As local authorities have been playing such a crucial role in the socio-economic development of municipalities, the aim of the paper was to identify positive or negative development factors in the Warmia and Mazury Voivodeship, in the opinion of the authorities (mayors) of rural and semi-urban (urban-rural) municipalities.

\section{THEORETICAL BACKGROUND}

Literature provides numerous classifications of local development factors. A quite synthetic and, at the same time, comprehensive approach was applied by Wong, who divided 11 factors into 2 groups (Wong, 2010). The first group included traditional factors (derived from works of Ricardo and Weber), among which the following could be distinguished: natural environment, geographical location, infrastructure, human resources, finance and capital, knowledge and technology, and finally structure of the economy. The second group of factors, called non-material, included: quality of living, institutions, entrepreneurship culture as well as local identity and image.

Local development has been particularly important in the context of (sustainable) rural development. Wilkin defines the rural area in two ways. On the one hand, highly-urbanized units with a relatively dense settlement network with the dominance of non-agricultural functions, not much different from small towns or suburban villa areas, recognized as a village. On the other hand, rural areas are traditionally perceived as monofunctional (agricultural) areas, with traditional buildings, low population density and a remote location (Wilkin, 2005). The peripheral character of areas located outside urban centres makes it possible to preserve traditional landscapes and their rural character. However, some analyses show that these areas usually have a low or very low level of development (Pomianek, 2017). The natural environment is an element of sustainable development which affects social and economic growth (Gwiaździńska-Goraj and Goraj, 2013). At the same time, environmental conditions and the presence of legally protected areas force commune authorities to carry out activities in line with the principles of a sustainable economy. It can be either an oppor- tunity or a barrier of municipal and entrepreneurial development. For example, in municipalities of the Warmia and Mazury Voivodeship, with a very low demographic potential, natural protected areas were recognized as a barrier to economic development (Pomianek, 2018). Geographical location is a universal factor, which municipal authorities have no influence over. Other traditional factors as well as non-material ones, pointed out by Wong (2010), can be modified by local authorities. Therefore, it is important to assess the local authorities' perception and awareness of development factors and local community needs, even though there is a wide range of factors shaping local development that makes it impossible to be unambiguously defined (Będzik and Brelik, 2015).

\section{MATERIALS AND METHODS}

The paper presents the results of a questionnairebased survey conducted from March to September 2017 in 100 municipalities of the Warmia and Mazury Voivodeship (including 67 rural and 33 semiurban ones). The voivodeship is known as one of the biggest and at the same time one of the most problematic regions in Poland. Answers of the municipal mayors were collected from $42 \%$ of surveyed selfgovernment units (the same percentage distribution in both groups of communes). The presented questions were multiple-choice, so the answers do not sum up to $100 \%$. The resulting structure of respondents (34\% in the Elblaski subregion, 26\% in the Ełcki subregion and $40 \%$ in the Olsztyński subregion) was in line with the structure of the surveyed population, which enables generalizations of findings to be made.

\section{RESULTS AND DISCUSSION}

In the opinion of local authorities of rural and semiurban municipalities in the Warmia and Mazury Voivodeship, the most important opportunities for local development were based on environmental (natural) resources, especially: climate and geographical location, but also location along water trails and tourist attractions. The second issue 
having a positive impact on local economic development was the involvement of different social groups in local problems, more important for rural authorities (Fig. 1). Over $1 / 3$ of respondents from semi-urban municipalities saw development opportunities in co-operation with national or foreign municipalities. However, in rural municipalities there was no indication of the possibility of co-operation with foreign municipalities, and only $12 \%$ of rural units were convinced of development opportunities through cooperation with national municipalities. Inter-municipal co-operation in the implementation of common goals may allow to achieve economies of scale (Teles, 2016), which in turn may be an important stimulus for local development - so important in rural (peripheral) areas.

Quality of technical infrastructure was also crucial for local self-governments; about $40 \%$ of them stated that a well-developed infrastructure was a driving force for the economic development of a municipality, whereas $32 \%$ of rural respondents and as many as $50 \%$ of semi-urban ones pointed to a low level of technical infrastructure as the second most important barrier of local development (Fig. 2).

The most popular barrier of local development was connected with a lack of funds, pointed out more often by rural authorities (75\%). It could cause problems with co-financing EU projects or the realization of investment. Indebtedness of a municipality (public debt or unpaid bank loans) was an obstacle to obtaining investment loans that could result in the lower development of technical and social infrastructure, considered to be other barriers of local development. Politicization of self-government administration was not a problem for rural respondents.

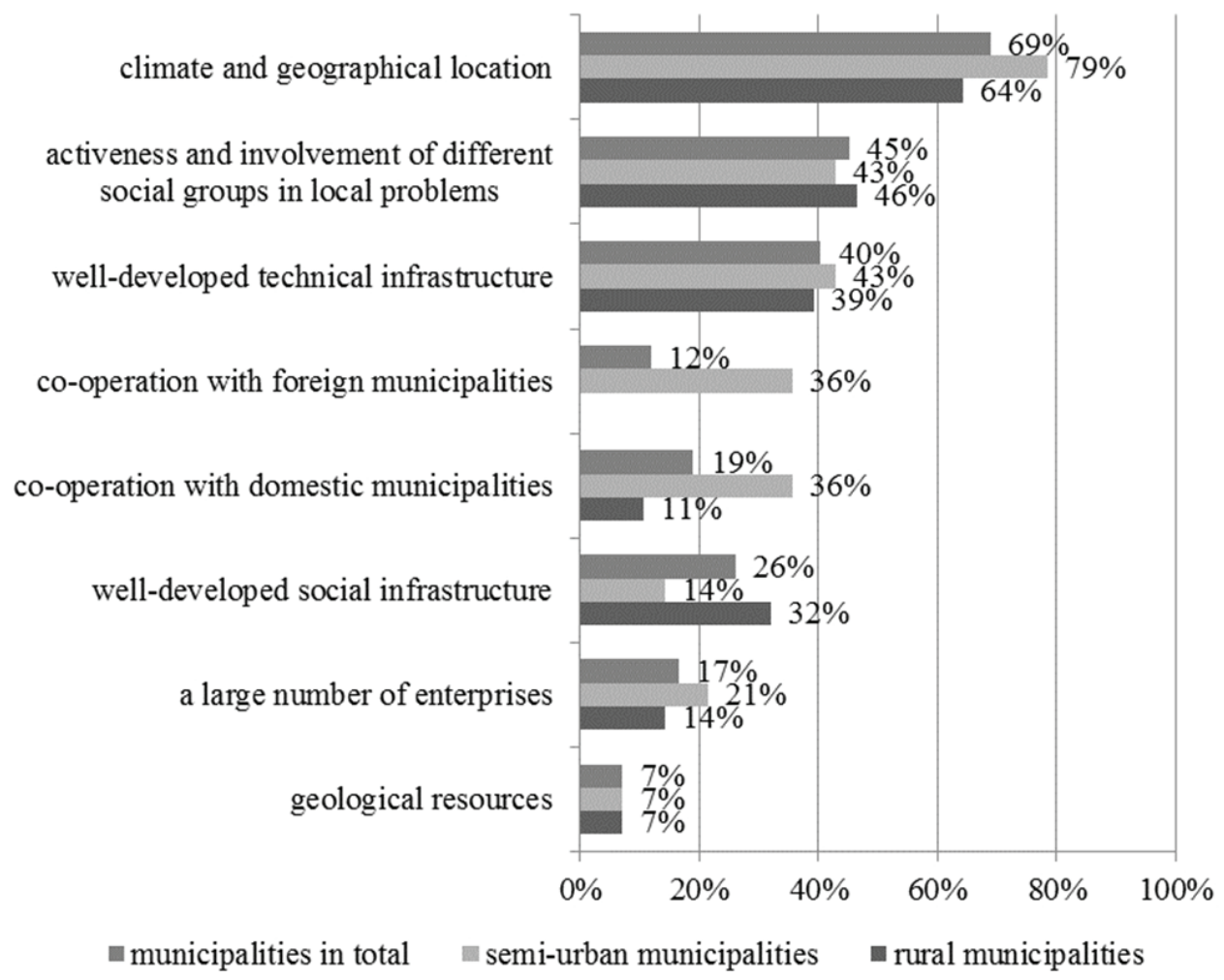

Figure 1. Opportunities for economic development of municipalities in the Warmia and Mazury Voivodeship, Poland, in the opinion of local authorities (2017)

Source: author's own research. 


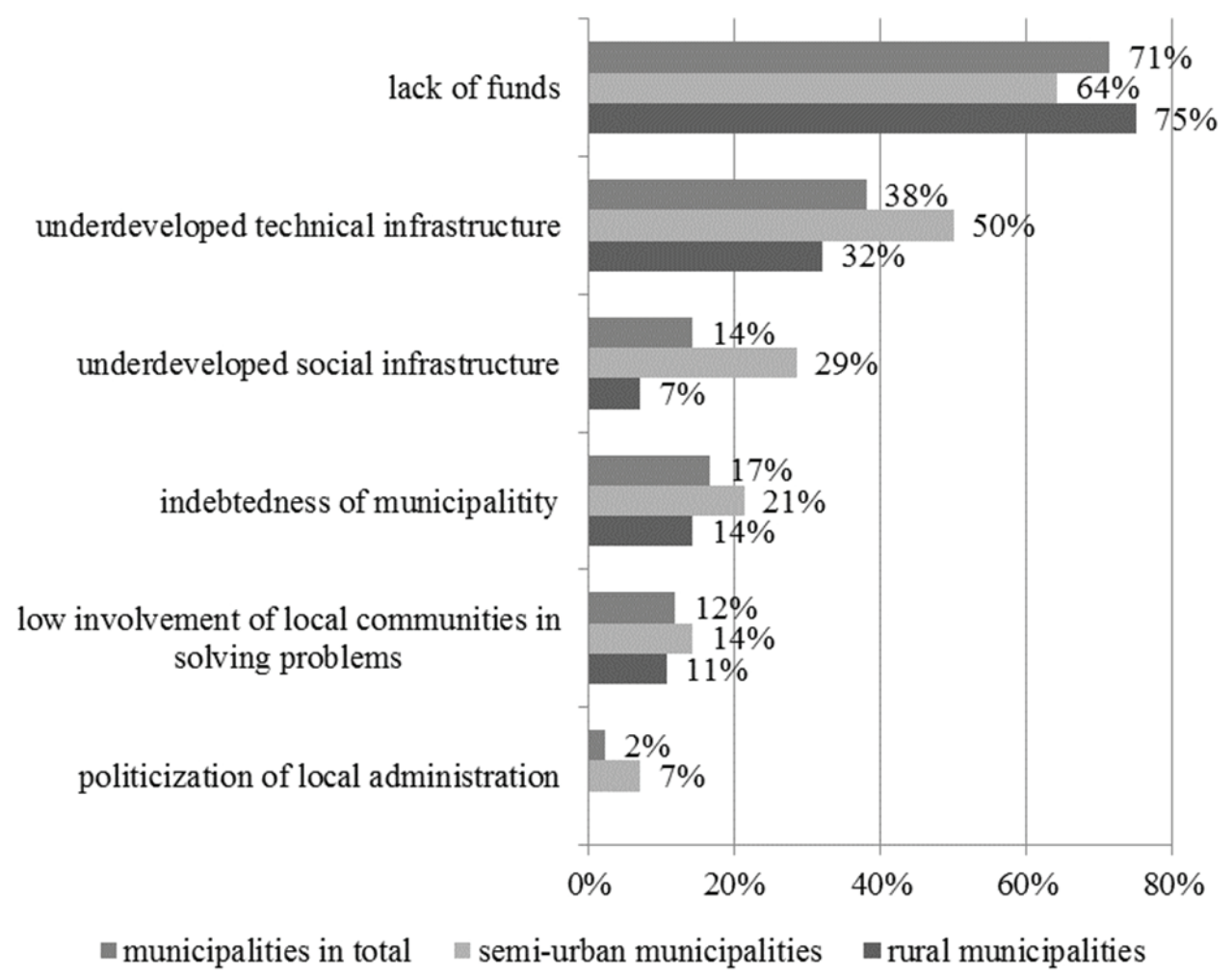

Figure 2. Barriers of economic development of municipalities in the Warmia and Mazury Voivodeship, Poland, in the opinion of local authorities (2017)

Source: author's own research.

\section{CONCLUSIONS}

Local authorities in rural and semi-urban areas of the Warmia and Mazury Voivodeship, Poland, have been aware of numerous opportunities and barriers of local economic development. Sometimes, if there is one barrier, it causes the formation of new ones. The best example is the shortage of own financial resources or municipal debt, which makes it impossible to finance investment from the local budget or to apply for EU funds, which require co-financing from the beneficiary's own resources. Most mayors make efforts to mitigate exogenous conditions by local activeness, such as co-operation with neighbouring or foreign municipalities or offering preferential tax rates to investors. Municipalities perceive the opportunity in applying for EU funds for projects aimed at improving the quality of life of local so- ciety, including the development of technical and social infrastructure. Inter-municipal co-operation in the implementation of common goals may not be popular within municipalities. In the case of rural communes in particular, this is a potentially unused opportunity of achieving a synergy effect - having an impact on local development, which is vital in rural (peripheral) areas.

\section{REFERENCES}

1. Będzik, B., Brelik A. (2015). Soft factors of local development. Zeszyty Naukowe Wyższej Szkoły Ekonomiczno-Społecznej w Ostrołęce, 3 (18), pp. 52-63.

2. Gwiaździńska-Goraj, M., Goraj, S. (2013). The contribution of the natural environment to sustainable development on the example of rural areas in the Region of Warmia and Mazury. Journal Rural Development, 6 (3), pp. 266-271. 
3. Klank, L. (2005). Ekonomiczne czynniki rozwoju lokalnego [Economic factors of local development]. In: Rosner, A. (ed.) Uwarunkowania i kierunki przemian społeczno-gospodarczych na obszarach wiejskich [Conditions and directions of socio-economic changes in rural areas]. IRWiR PAN, Warszawa.

4. Kłodziński, M. (1996). Wielofunkcyjny rozwój terenów wiejskich w Polsce i w krajach Unii Europejskiej [Multifunctional development of rural areas in Poland and in European Union countries]. Wydawnictwo SGGW, Warszawa.

5. Kłodziński, M., Rosner, A. (1995). Wielofunkcyjny rozwój terenów wiejskich a polityka regionalna [Multifunctional development of rural areas and regional policy]. In: Polityka regionalna $\mathrm{w}$ rozwoju obszarów wiejskich [Regional policy in the development of rural areas]. Wydawnictwo SGGW, Warszawa.

6. Kotala, A., Basaj, M. (2004). Perspektywy gospodarczego rozwoju obszarów wiejskich w ocenie drobnych przedsiębiorców Małopolski [Prospects for economic development of rural areas in the assessment of small entrepreneurs in Małopolska]. In: Urban, S. (ed.) Agrobiznes 2004. Sytuacja agrobiznesu w Polsce po przystapieniu do Unii Europejskiej [Agrobusiness 2004. The agribusiness situation in Poland after joining the European Union]. Vol. I. Prace Naukowe Akademii Ekonomicznej we Wrocławiu, 1015, pp. 436-442.

7. Pomianek, I. (2017). Socio-economic development in Poland's Warsaw Metropolitan Area and the rest of Mazovieckie voivodship. Rural development and entrepreneurship: bioeconomy production and co-operation in agriculture. In: Proceedings of the International Scientific Conference, Jelgava 27-28.04.2017, pp. 153-160.

8. Pomianek, I. (2018). Preparation of local governments to implement the concept of sustainable development against demographic changes in selected rural and urban-rural communes of the Warmia and Mazury Voivodeship. Problemy Zarządzania - Management Issues, 3 (75), pp. 39-

9. Teles, F. (2016). Local governance and inter-municipal cooperation. Palgrave Macmillan, New York.

10. Wiatrak, A.P. (2006). Skala regionalna i lokalna - istota, rozwój i zarządzanie [Regional and local scale - essence, development and management]. Problemy Zarządzania, 13 (3), pp. 8-22.

11. Wiatrak, A.P. (2011). Strategie rozwoju gmin wiejskich [Development strategies of rural municipalities]. IRWiR PAN, Warszawa.

12. Wilkin, J. (2005). Lepszy świat - polska wieś za 25 lat [Better world - Polish countryside in 25 years]. In: Wilkin, J. (ed.) Polska wieś 2025. Wizja rozwoju [Polish village 2025. Vision of development]. Fundusz Współpracy, Warszawa, p. 41.

13. Wong, C. (2010). Determining Factors for Local Economic Development: The Perception of Practitioners in the North West and Eastern Regions of the UK. Regional Studies, 32 (8), pp. 707-720. DOI: 10.1080/0034 3409850119409

14. Zalewski, A. (2006). Uwarunkowania skuteczności stymulowania rozwoju lokalnego [Determinants of the effectiveness of stimulating local development]. Problemy Zarządzania, 13 (3), pp. 23-38. 